\title{
Trends in the abundance of Cantabrian Capercaillie Tetrao urogallus cantabricus at leks on the southern slope of the Cantabrian Mountains, north-west Spain
}

\author{
CÉSAR J. POLLO, LUIS ROBLES, JUAN M. SEIJAS, ÁNGEL \\ GARCÍA-MIRANDA and RAFAEL OTERO
}

\section{Summary}

We analysed the trend of the number of singing males of Cantabrian Capercaillie Tetrao urogallus cantabricus in 207 leks on the southern slope of the Cantabrian mountains, northwest Spain, in the period 1981 to 2003. The area of occupancy in 1981-1982 covered up to approximately 2,070 $\mathrm{km}^{2}$, but in 2000-2003 it was $693 \mathrm{~km}^{2}$, a $66 \%$ area reduction in 22 years. The $1981-1982$ census estimated a minimum number of 274 singing male Capercaillie on the southern slope, but in 2000-2003 only an estimated 81 males were recorded, a reduction of $70 \%$. A linear regression was used to detect and describe the changes in the size of the total population of the southern slope as well as individual subpopulations. The overall trend for the total subpopulations was a significant decrease in the number of males $\left(y=39.94^{-0.018 x}\right.$; $\left.R^{2}=0.944, P<0.001\right)$. The negative regression slopes indicated that the number of males had fallen in all the subpopulations considered. In the western core area the greatest annual mean rate of decline was detected in the Sierra de Picos de Ancares subpopulation $(-6.22 \%)$ and in the eastern core in the Sierra de Riaño subpopulation $(-3.43 \%)$. The principal local limiting factors (habitat fragmentation, human disturbance, small population size and competition) that have caused the population decline are discussed, together with the demographic, genetic and evolutionary consequences for the surviving subpopulations.

\section{Introduction}

Capercaillie Tetrao urogallus is considered an important indicator and umbrella species for boreal and montane forest biodiversity conservation (Potapov and Flint 1989, Moss et al. 1991, Valkeajärvi and Ijäs 1993, Storch 1995, Suchant 2001, Suter et al. 2002). The species has a contiguous distribution in the boreal forest, but in western and central Europe is scattered, due primarily to the patchy distribution of forest that remained after the last ice age. The isolation has led to the formation of subspecies, as in the Pyrenees (T. u. aquitanicus) (Potapov and Flint 1989) and the Cantabrian mountains (T. u. cantabricus) (Castroviejo 1967, 1975).

Since the second half of the twentieth century, anthropogenic habitat deterioration and fragmentation, human disturbance, increasing predator and competitor densities and possibly climate change have led to an overall population decline and range contraction of the Capercaillie in western and central Europe (Storch 2000, Moss et al. 2001, Segelbacher et al. 2003). Many populations have disappeared and most of the 
remaining ones are isolated and small (Blair et al. 1997). Capercaillie is Red-Listed throughout western and central Europe (Storch 2000).

T. $u$. cantabricus inhabits both slopes on the Cantabrian mountains, geographically isolated and separated from the nearest neighbouring metapopulation in the Pyrenees by a distance of $300 \mathrm{~km}$ (Storch 2000). On the northern slope (Asturias and Cantabria provinces) the range is continuous with an incipient partition in the central section, but on the southern slope (León and Palencia provinces) was already separated into two cores in the 198 os without a presence in the central area (Figure 1), where there had been Capercaillies in the 1960s and 1970s (Castroviejo 1975).

Cantabrian Capercaillie occurs in mature beech Fagus sylvatica forest and mixed forest of beech and oaks Quercus robur, Q. petraea and Q. pyrenaica, and its diet consists of beech buds, catkins of birch Betula alba and holly leaves Ilex aquifolium. Other European Capercaillie subspecies inhabit coniferous forests (pine, spruce, fir, etc.) and feed mainly on conifer needles. However, as in other European subspecies, presence of the Cantabrian Capercaillie is associated with bilberry Vaccinium myrtillus, which represents an important component of its diet (Rodríguez and Obeso 2000).

Cantabrian Capercaillie is the most endangered of the 12 subspecies recognized, listed in Appendix II of the Berne Convention, and qualifies to be listed as Endangered (Storch 2000) according to the IUCN Red List Categories. In 1998 it was reclassified in the Spanish Catalogue of Threatened Species as 'Vulnerable' (Real Decree 439/1990 and 9 July 1998 Order).

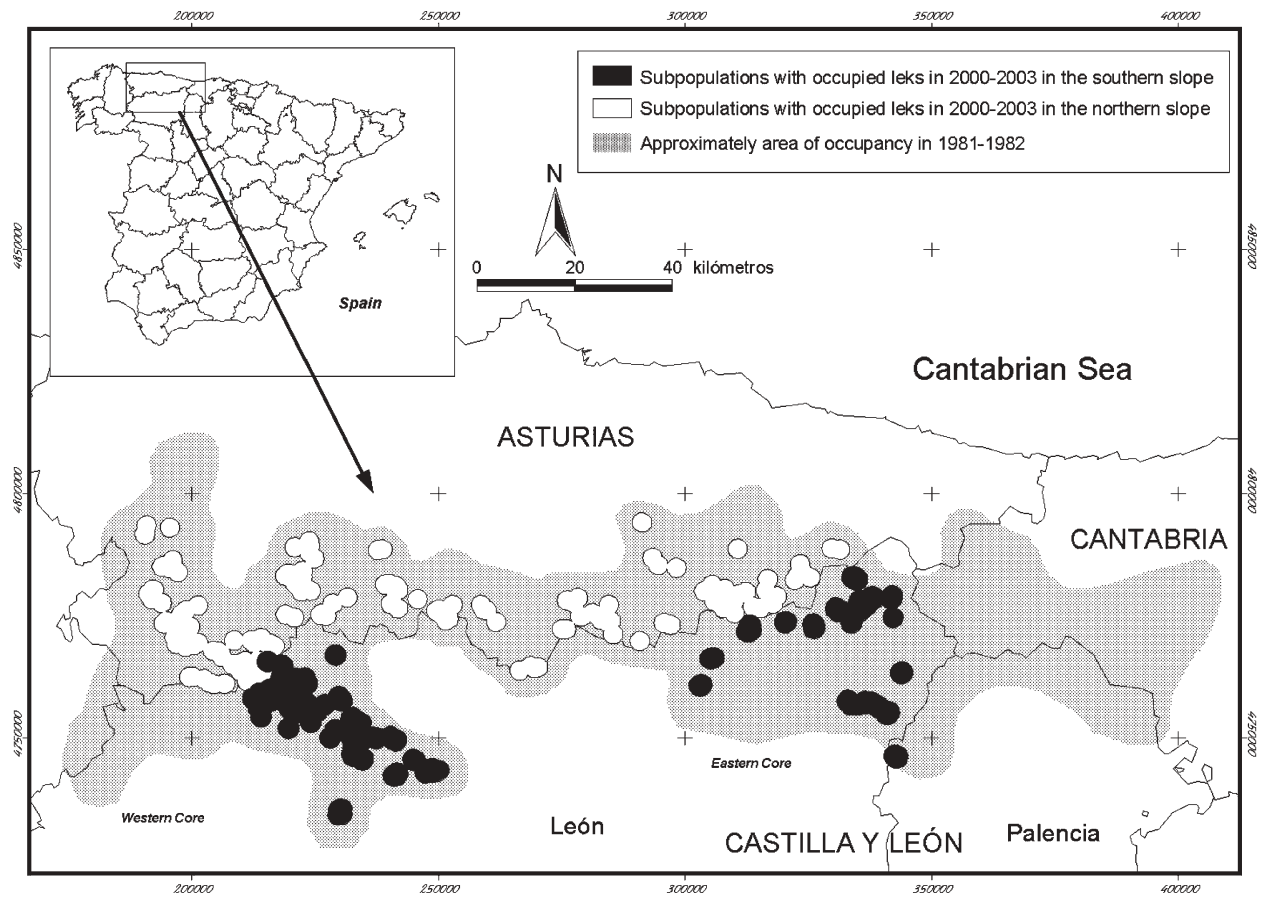

Figure 1. Map of the area of occupancy of Cantabrian Capercaillie in the Cantabrian mountains, Spain, in 2000-2003. 
At present T. u. cantabricus subspecies inhabits a 2,000 $\mathrm{km}^{2}$ range in the Cantabrian mountains. In the 1980 os and 1990 s the metapopulation demonstrated a clear reduction (Pollo et al. 2003a) both in number of males and in the 'area of occupancy' (IUCN 2001), mainly in the peripheral areas of Sierra de Picos de Ancares (Galicia and Castilla y León), Palencia province, eastern Cantabria and northern locations in Asturias (Pollo 2001).

The objectives of this study were to analyse the trend in the number of singing males of Cantabrian Capercaillie Tetrao urogallus cantabricus on the southern slope of the Cantabrian mountains, in the period 1981-1982/2000-2003, to determine the form of decline in each subpopulation and the relationship to its geographical situation.

\section{Study area}

The Cantabrian mountains extend along the north-west of Spain, parallel to the Cantabrian Sea coast, forming a $480 \mathrm{~km}$ east-west wall. The northern slopes drop steeply to the Bay of Biscay while the southern slopes descend gradually to Spain's arid central plateau, the valley of the Duero river, which generates a great variety of landscapes with different botanical characteristics. The mountains comprise a series of high ridges in the autonomous communities of Galicia, Asturias, Cantabria and Castilla and León, Torre Cerredo $(2,648 \mathrm{~m})$ in the Picos de Europa group in the central section being the highest peak (London Times 1999).

These mountains are geologically of similar origin to the Pyrenees. In the west the soil is siliceous and the forest cover is fundamentally deciduous forests of $Q$. robur and Q. pyrenaica, while in the eastern zone on calcareous soil beech forests $F$. sylvatica prevail. Frequently the woods are mixed with different and isolated elements: Sorbus spp., Fraxinus excelsior, Acer spp., I. aquifolium, Taxus bacatta, Tilia platyphyllos and Corylus avellana. The upper part of the forest is formed by a long zone of Betula alba that tends to disappear towards the East.

The subalpine cover, without an arborescent layer, consists of a scrub of Erica arborea, Genista florida, Ulex cantabricus and Juniperus spp. Rocky outcrops are numerous and support Vaccinium myrtillus and Festuca spp. (Blanco et al. 1997).

These mountains, together with the Pyrenees, are the last redoubt of the different species of flora and fauna that occupied the Iberian Peninsula during the Quaternary glacial periods. The Central, Eastern and Western massifs of the Picos de Europa are all contained within the Picos de Europa National Park, a 1995 expansion of the smaller Covadonga National Park.

\section{Methods}

Bird survey

In 1981-1982, 1987-1989, 1998 and 2000-2003 the numbers of singing males were counted in 234 leks on the southern slope of the Cantabrian mountains. Due to inadequate counting (absence of counting in certain years) we included only 207 leks (approximately $45 \%$ of the entire Cantabrian population) that were regularly observed, these leks corresponding to Io different subpopulations: eight in the eastern 
core (with 109 leks) and two in the western (with 98 leks). Three subpopulations on the southern slope that were not included in the sample contained only small numbers of males and are composed of very few leks.

Also we have used the data of the southern slope of the Cantabrian mountains provided by the global census (del Campo and García-Gaona 1983) to determine the number of singing males in 1981-1982 and the approximate area of occupancy.

\section{Lek count technique}

The number of lekking male Capercaillie is the traditional way of measuring the subpopulations. The number of males attending leks varies between sites, and although males are present throughout the year near lek sites, peak numbers occur during the breeding season in early mornings in spring (March, April and May). During the visits the maximum numbers of displaying males was recorded and non-territorial males were not considered.

The geographical positions of the leks were established using the experience of field personnel (Agentes and Celadores de Medio Ambiente) of the Junta de Castilla y León and several distribution maps (Castroviejo et al. 1974, del Campo and García-Gaona 1983, Fernández et al. 1992, L. Robles in litt. 1998, 1999, J. Seijas in litt. 1999, pers. obs.). This information has been incorporated in a GIS application. The position of the leks had not changed over the years.

In the Cantabrian mountains we define a lek as a ground that includes one or two different traditional communal courtship displaying Capercaillie, generally separated by less than $2 \mathrm{~km}$ in continuous favourable habitat. At present the Cantabrian Capercaillie population is declining and there are more solitary males than communal leks. The whole set of leks of a side-valley or a continuous forested habitat is a subpopulation, generally separated by intervening ridges.

The percentage of occupied leks has been used to determine the range of Cantabrian Capercaillie on the southern slope of the Cantabrian mountains. The range has been equated to the 'area of occupancy' according to the criteria and definitions of the IUCN (2001a, b), which defines this area as the smallest area essential for the survival of the population, delineated by a circle of $2 \mathrm{~km}$ radius around the occupied leks. The resultant area equates quite well to the home range of the species (Pollo et al. 2003a).

\section{Trends in abundance}

The analyses were carried out on the maximum number of males recorded per lek per year. Leks with missing data in certain years have not been included in the analysis, and we omitted 27 of the total of censused leks for this reason. To ensure that the variables were normally distributed, as required for the tests used, the variable number of males was transformed into $\log$ (number of males +1 ). Linear regression (Sokal and Rohlf 1995) was used to detect and describe the changes in the sizes of the overall subpopulations on the southern slope of the Cantabrian mountains (by combining the results from all the leks studied) and of each individual subpopulation (by combining the results for all the leks in each subpopulation). Residuals normality was checked by the Kolgomorov-Smirnov test (Zar 1984). The percentage of birds lost each year was calculated by $\exp ^{\text {(slope) }}-1$ (Harris 1986). 


\section{Results}

In 1981-1982 the distribution of Cantabrian Capercaillie on the southern slope of the Cantabrian mountains was in two large cores: eastern and western. However, at present the distribution of the Capercaillie on the southern slope is fragmented into 13 small subpopulations: four in the western area and nine in the eastern (Figure I). In 2000-2003, six (five in the eastern and one in the western) very small subpopulations had only one singing male.

The area in 1981-1982 covered up to approximately 2,070 $\mathrm{km}^{2}: 972$ in the western core and 1,098 in eastern. But in 2000-2003 the area of occupancy was $693 \mathrm{~km}^{2}$ : $413 \mathrm{~km}^{2}$ in the western and $280 \mathrm{~km}^{2}$ in the eastern (Table 1 ). There has thus been a reduction of $66 \%$ in area in the last 22 years: $58 \%$ in the western area and $74 \%$ in the eastern.

The 1981-1982 census estimated a minimum number of 274 singing male Capercaillie in the subpopulations studied ( 207 leks) on the southern slope. The surveys carried in 1987-1989 and 1998 estimated 219 and 94 males, while in 2000-2003 the estimate was only 81 males, a reduction of $70.4 \%$ with respect to the $1981-1982$ census: $36.7 \%$ in the western core and $86 \%$ in the eastern (Table 1 ).

The number of Capercaillie males present in the leks during the breeding season varied each year, but the overall trend for all the subpopulations on the southern slope of the Cantabrian mountains was a significant decline in the number of males $(P<0.001$; Figure 2, Table 2). Changes in abundance differed according to the subpopulation and core (Figures 3,4$)$. The slopes of the regression lines were significantly different from $\mathrm{O}(P<\mathrm{O} . \mathrm{OI})$ for six of the ten subpopulations.

The reduction in the number of males was less in Villablino-Murias de Paredes subpopulation, but the negative regression slopes indicated that the number of males had decreased in all the subpopulations of the two cores; in the western core the mean annual rate of increase was lowest in the Sierra de Picos de Ancares subpopulation $(6.22 \%)$ (Figure 5) and in the eastern core (Table 2 ) in the Sierra de Riaño subpopulation $(3.43 \%)$ (Figure 6$)$. The residuals of all of the linear regressions were normally distributed $(P<0.05)$.

\section{Discussion}

We observed a significant overall downward trend in the number of male Capercaillie in the leks sampled and a reduction in the area of occupancy. The situation of the eastern subpopulations is worse than that of the western, where the more stable subpopulations are located (Pollo et al., 2003a).

Capercaillie subpopulations on the southern slope of the Cantabrian mountains showed a decreasing trend; however, it is possible to categorize the subpopulations into two groups. Peripheral subpopulations in the western (Sierra de Picos de Ancares) as well as in the eastern core (North Palencia, Valdeón-Sajambre and Sierra de Riaño) have declined faster than central subpopulations, mainly as of 1990. At the edge of the area of occupancy, local extinctions have quickly reduced both the number of males and the distribution; in Sierra de Picos de Ancares and North Palencia subpopulations there is only occasional presence, and the situation is that of virtual extinction.

These results can probably be extrapolated to other subpopulations of this slope the sample analysed included more of the $88 \%$ of the known leks and were carried out 


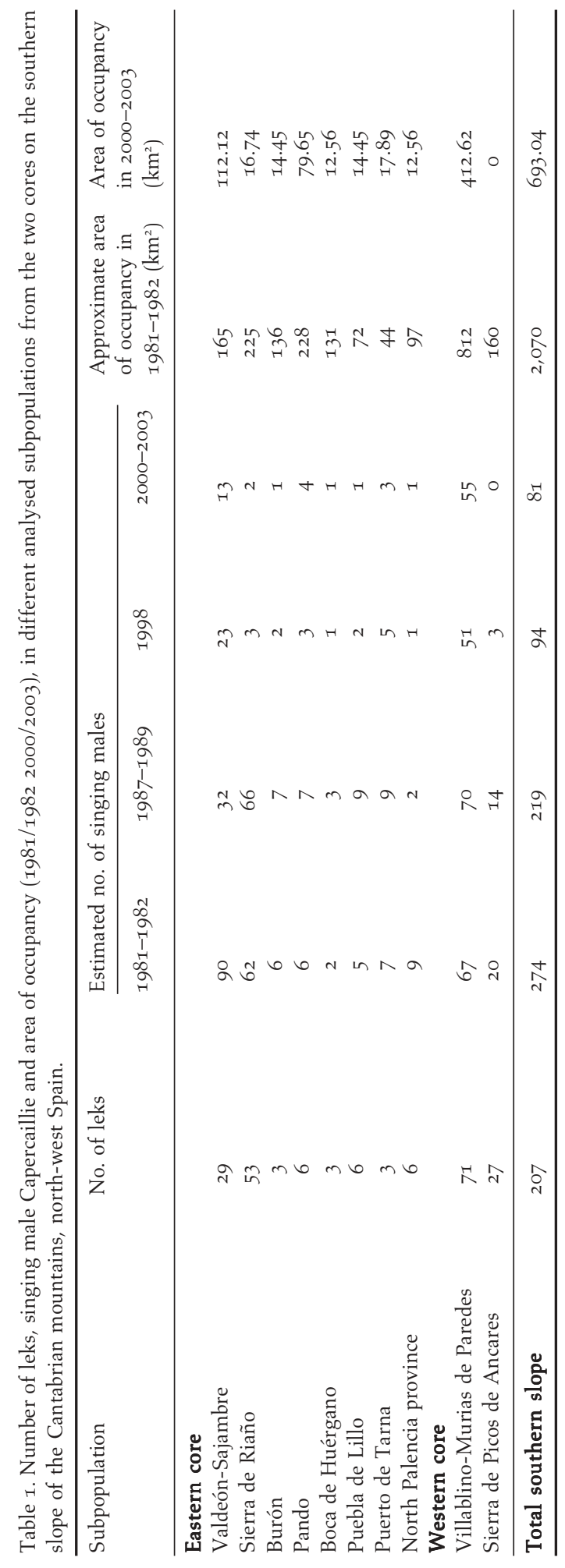




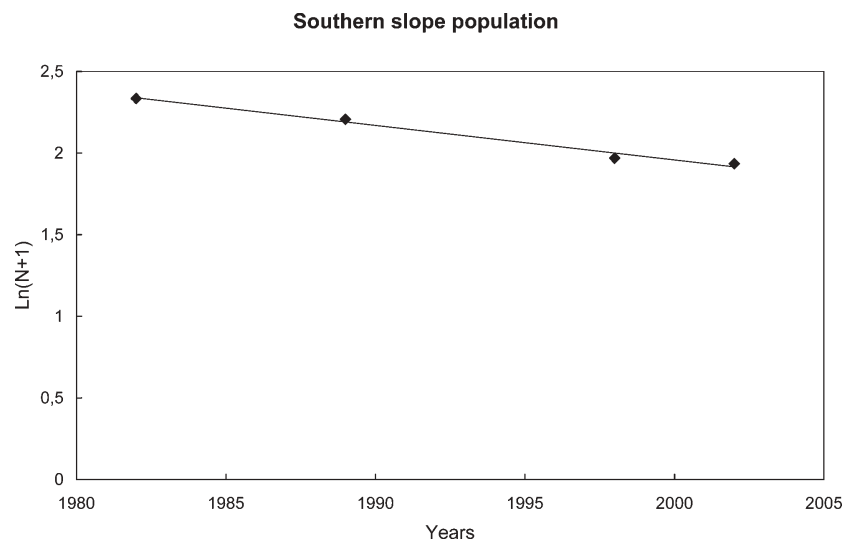

Figure 2. Changes in the number of male Capercaillie counted in 1981-1982, 1987-1989, 1998 and 2000-2003, in a sample of 207 leks corresponding to 10 subpopulations on the southern slope of the Cantabrian mountains, Spain. The unbroken line is the regression line. The regression parameters are in Table 2.

Table 2. Trends in the annual abundance of singing male Capercaillie for 1o subpopulations of the southern slope of the Cantabrian mountains between 1981 and 2003, where $y=$ Constant + Slope $x$. Percentage of birds lost each year is given by $\exp ^{\text {(Slope) }}-1$.

\begin{tabular}{|c|c|c|c|c|c|c|}
\hline Subpopulation & Constant & Slope & $\%$ birds lost each year & $R^{2}$ & $F$ ratio & $P$ \\
\hline \multicolumn{7}{|l|}{ Eastern core } \\
\hline Valdeón-Sajambre & 70.39 & -0.033 & $-3 \cdot 34$ & 0.927 & 90 & $<0.001$ \\
\hline Sierra de Riaño & 71.61 & -0.034 & -3.43 & 0.859 & 42.94 & $<0.001$ \\
\hline Burón & 47.25 & -0.023 & -2.34 & 0.762 & 32.12 & $<0.001$ \\
\hline Pando & $15 \cdot 73$ & -0.006 & -0.69 & 0.455 & 5.84 & 0.038 \\
\hline Boca de Huérgano & 15.29 & -0.007 & -0.74 & 0.074 & 0.72 & 0.404 \\
\hline Puebla de Lillo & 29.13 & -0.014 & -1.42 & 0.33 & 4.94 & 0.045 \\
\hline Puerto de Tarna & 23.83 & -0.011 & -1.15 & 0.696 & 13.74 & 0.008 \\
\hline North Palencia province & 62.24 & -0.031 & -3.05 & 0.741 & 20.03 & 0.002 \\
\hline \multicolumn{7}{|l|}{ Western core } \\
\hline Villablino-Murias de Paredes & 10.82 & -0.004 & -0.45 & 0.356 & 2.22 & 0.149 \\
\hline Sierra de Picos de Ancares & 129.02 & -0.062 & -6.22 & 0.93 & 80.82 & $<0.001$ \\
\hline Total southern slope & 39.94 & -0.018 & -1.89 & 0.944 & $85 \cdot 3$ & $<0.001$ \\
\hline
\end{tabular}

over a long period of time) and to the whole of Cantabrian Capercaillie metapopulation. The viability of the other southern subpopulations represented by only one or a very few occupied leks is uncertain and the contribution of the leks not included in the sample for species dynamics is probably very limited.

Numerous limiting factors influence the population dynamics of the Capercaillie and threaten their survival over all their distribution range, indicating that some global factors are involved (habitat degradation, loss and fragmentation, climate change) (Storch 2000, 2001). But in isolated populations, others local limiting factors (small population size, human disturbance, collisions, predation, competition and exploitation) in addition to the negative effect may be operating.

In the Cantabrian mountains the forest patches with occupied leks have a significantly greater area, smaller perimeter and are located close to other fragments 

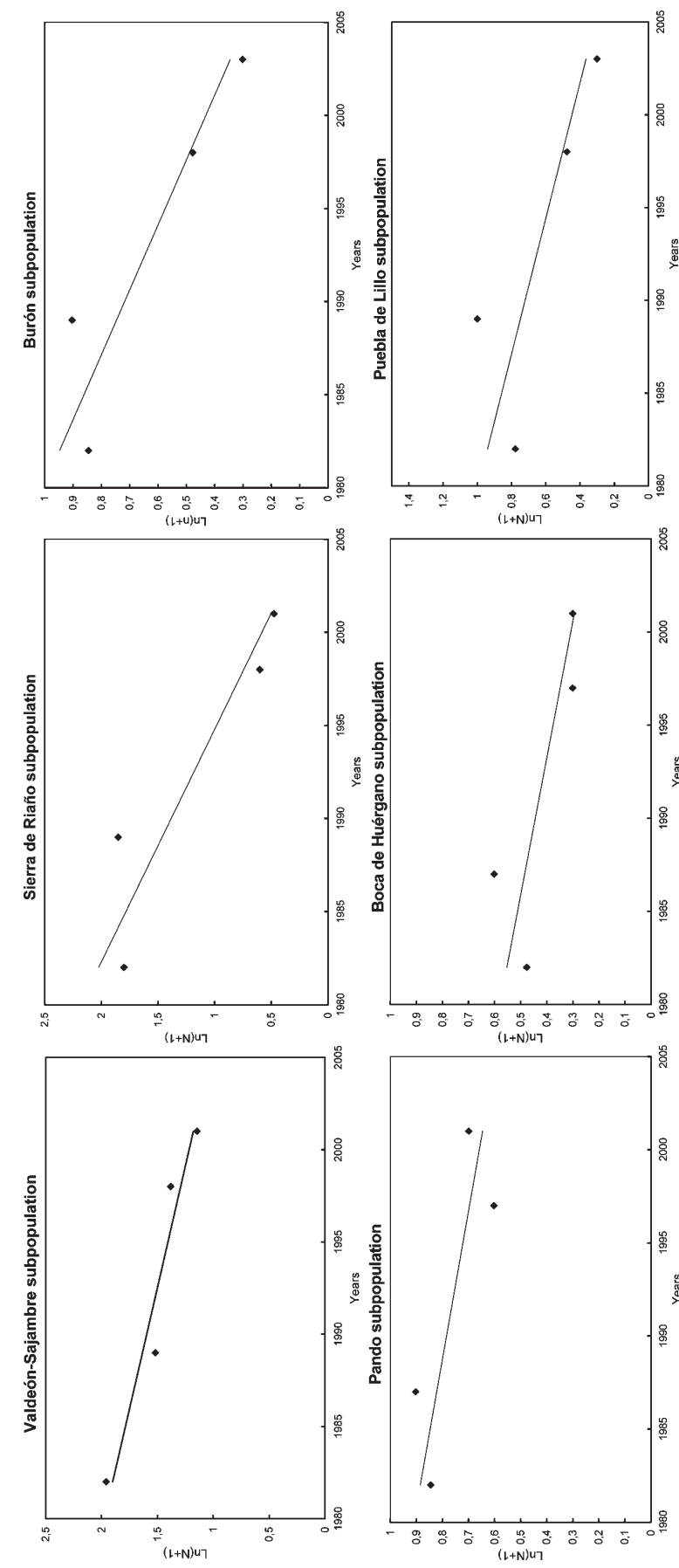

के

:

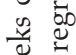

음

눙.

$\frac{0}{2} \Xi$

हี

क

음

\%ั

s.

\&.

चे के

है ज

مू.

$\rightarrow 5$

कूे है

Tे

o.

小

I

空岁

$\Xi$ ڤั

एक

5

$8=$

$\stackrel{\circ}{\Xi}$

ฐ్ّ

ठิ

ฮั ธั

छ

눙 문

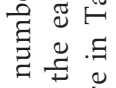

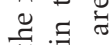

$\exists \square$

总

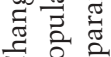

ن

ले के

言党范 

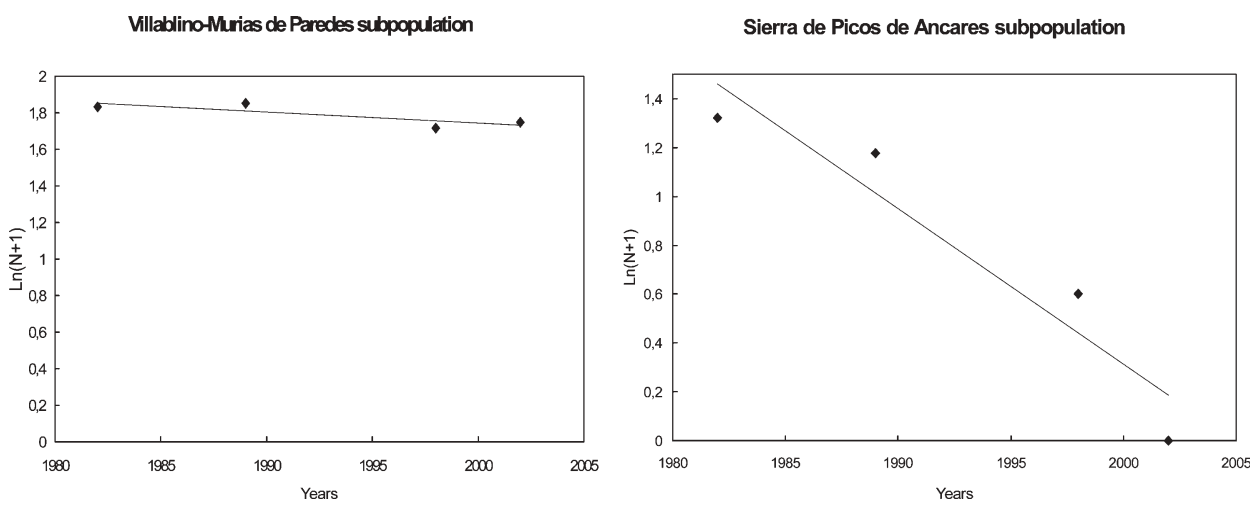

Figure 4. Changes in the number of male Capercaillie counted in 1981-1982, 1987-1989, 1998 and 2000-2003, in a sample of 98 leks corresponding to two subpopulations in the western core on the southern slope of the Cantabrian mountains, Spain. The unbroken line is the regression line. The regression parameters are in Table 2.

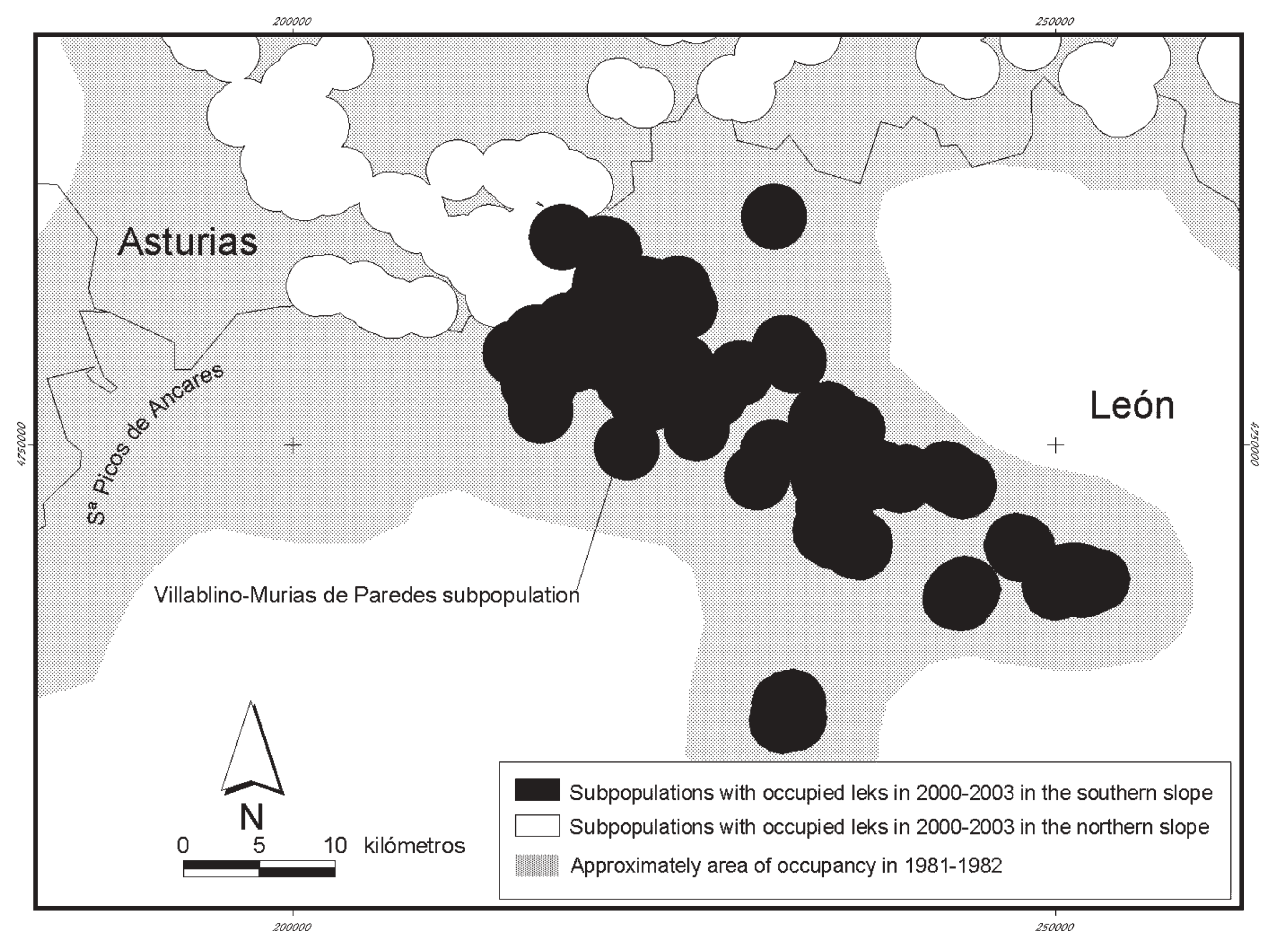

Figure 5. Map of the location of the populations of Cantabrian Capercaillie in the western core of the southern slope in the Cantabrian Mountains, Spain, in 2000-2003.

with occupied leks (Obeso and Bañuelos 2003, Pollo et al. in press.). In the last two decades, the fragments of forests from which the Capercaillie has disappeared have a smaller area and are the most isolated, moreover being located close to the edge of the range in both cores of the southern slope (Sierra de Picos de Ancares and North 


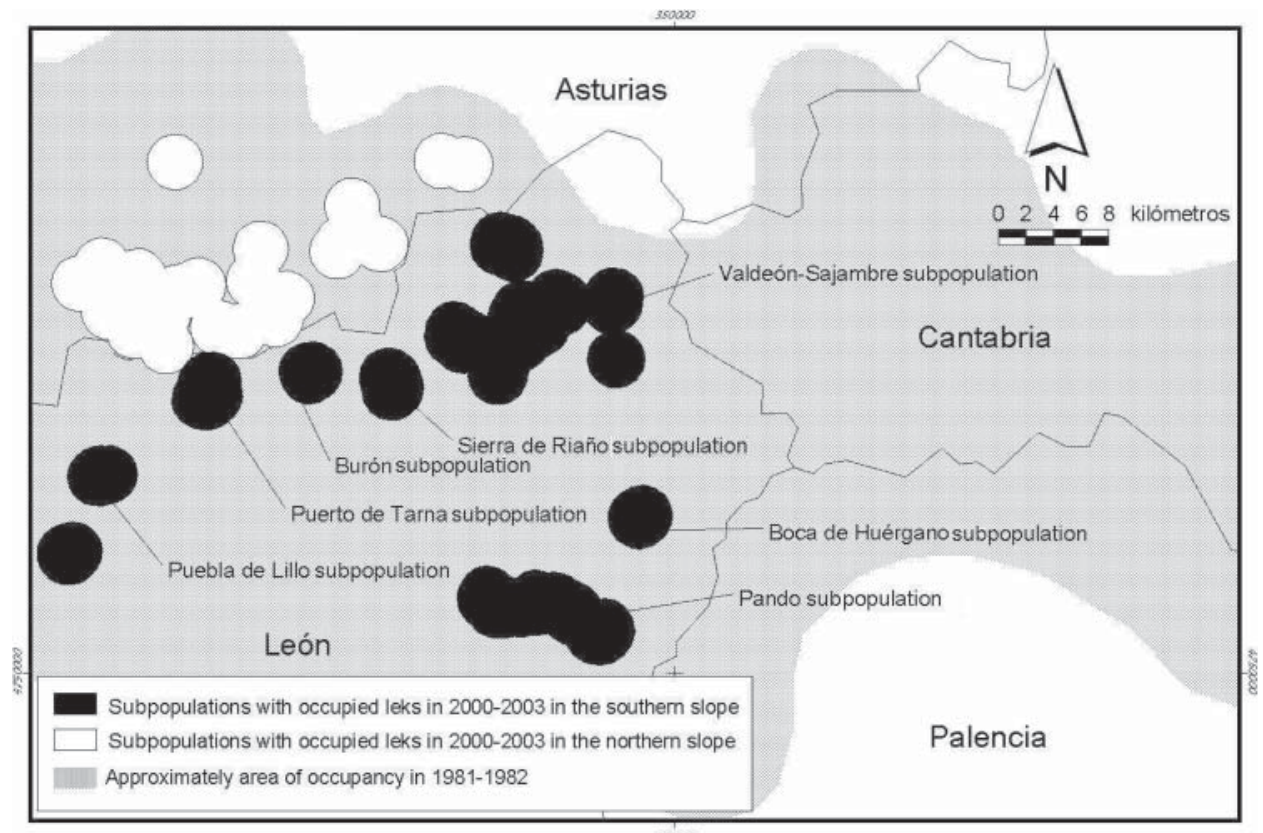

Figure 6. Map of the location of the populations of Cantabrian Capercaillie in the eastern core of the southern slope in the Cantabrian Mountains, Spain, in 2000-2003.

Palencia subpopulations), suggesting that fragmentation is playing an important role in the population dynamics (Pollo et al. in press).

Forest utilization is a major anthropogenic factor influencing forest grouse (Storch 2000) and forestry practices are probably a major factor limiting Capercaillie numbers (Rolstad and Wegge 1989, Rolstad 1989, 1991, Storch 1997, European Commission 2001). In recent years many inadequate sylvicultural operations in the Cantabrian mountains, unable to fulfil the birds' habitat requirements, have caused significant changes in forest structure (species, density and height of trees and ground vegetation) and dynamics that affect the distribution and population dynamics of Capercaillie.

The forest habitat of Cantabrian Capercaillie would benefit from appropriate and carefully planned forest management, limiting forestry operations to times outside the breeding, incubation and rearing seasons and before the onset of winter (vital periods), and delimiting critical areas (Pollo 2001).

Practically all the subpopulations of Capercaillie in the Cantabrian mountains live in a Natura 2000 (Ecological European Network, 79/409 and 92/43 Directives) forest site. Forestry practices should be adapted to maintain or improve the conservation value of the site for this species and to secure the special characteristics and functions of these areas (European Commission 2003), modifying the forestry measures to meet the special habitat needs of the Capercaillie (Suchant and Schäfer 2002). The management should be aimed at achieving nature conservation objectives, priorities on Natura 2000 sites (European Commission 2003).

In the eastern core red deer and Capercaillie are positively associated in the territory. In the last two decades red deer numbers have been increasing while for the 
Capercaillie declining populations and significant negative correlations were found for several management areas (Pollo et al. 2003b). The high densities of red deer can have a detrimental effect on the Capercaillie habitats by damaging the ground vegetation, mainly bilberry shrubs.

Disturbance by tourism activities is a serious threat to local Capercaillie populations in some regions of Europe (Storch 2000, European Commission 2001). In the Cantabrian mountains the tourist infrastructures and activities are one of the contributing factors to the Capercaillie's decline, as in recent years a network of cycling and hiking tracks has been created.

Is necessary to implement an integrated resource management plan which incorporates the interests of forestry, tourism and conservation, as have been initiated in other countries (e.g. Austria, Finland, France, Germany, Switzerland; Ménoni and Magnani 1998, Zeiler and Glänzer 1998, Suchant and Schäfer 2002). Successful harmonization between nature conservation and forestry and touristic use is necessary for the survival of the Cantabrian Capercaillie in the long term (Suchant and Schäfer 2002).

The surveys carried out in 20002003 over the entire Cantabrian Capercaillie metapopulation estimated the population at $627 \pm 41$ individuals, of which $501 \pm 34$ would be adults (Pollo et al. 2003a). A demographic model based on Bavarian Alpine populations suggests a minimum viable population size of the order of 500 birds (Grimm and Storch 2000), but genetic data show clear signs of reduced variability already in the range up to 1,000 birds, which indicates that a demographic minimum population of 500 birds may be too small to maintain high genetic variability (Segelbacher et al. 2003).

The reduction and fragmentation of Cantabrian Capercaillie metapopulation system not only leads to demographic consequences (range contractions, local extinctions, low reproduction rate), but probably also has significant genetic and evolutionary consequences for surviving populations. As a consequence, one of the principal management measures for the species and its habitat will be to identify the communication corridors and to ensure the connectivity between the different populations, permitting genetic flow and dispersal movements of the birds (Segelbacher et al. 2003).

The counting of males at leks is a important step towards understanding the demography of the Cantabrian Capercaillie. However, other information (habitat use in different seasons, breeding success, predation, genetic variability, etc.) is necessary to determine the limiting factors and causes of the decline, in order to focus suitable management options (Sachot 2002).

\section{Acknowledgements}

We thank field personnel (Agentes and Celadores de Medio Ambiente) of the León Environment Territorial Service of the Junta de Castilla y León Regional Authority. Two anonymous reviewers provided interesting suggestions.

\section{References}

Blair, M., Bijlsma, R. and Hagemeijer, W. (1997) The EBCC atlas of European breeding birds. London: T. \& A. D. Poyser. 
Blanco, E., Casado, M. A., Costa, M., Escribano, R., García, M., Génova, M., Gómez, A., Gómez, F., Moreno, J. C., Morla, C., Regato, P. and Sainz, H. (1997) Los bosques ibéricos. Una interpretación geobotánica. Barcelona: Ed. Planeta.

Castroviejo, J. (1967) Eine neue Auerhuhnrasse von der Iberischen Halbinsel. J. Ornithol.108: 220-221.

Castroviejo, J. (1975) El Urogallo en España. Madrid: Publicaciones del CSIC Monografías de la Estación Biológica de Doñana, 3.

Castroviejo, J., Delibes, M., García-Dory, M. A., Garzón, J. and Junco, E. (1974) Census of the Cantabrian Capercaillie (Tetrao urogallus cantabricus). XIth. Int. Congr. Game Biol. (Estocolmo 1973): 203-223.

del Campo, J. C. and García-Gaona, J. F. (1983) Censo de urogallos en la Cordillera Cantábrica. Nat. Hispan. 25: 1-32.

European Commission (2001) Period of reproduction and prenuptial migration of Annex II Bird Species in the EU. Key concepts of article 7(4) of Directive 79/409/EEC. DG Env B2 Nature and Biodiversity.

European Commission (2003) Natura 2000 and forests. Challenges and opportunities. Interpretation guide. DG Env B2 Nature and Biodiversity.

Fernández, A., Martínez, A. and Palomero, G. (1992). Bases para la conservación del Urogallo cantábrico (Tetrao urogallus cantabricus) en Castilla y León. Consejería de Medio Ambiente y O.T. Junta de Castilla y León. Unpublished work.

Grimm, V. and Storch, I. (2000) Minimum viable population size of capercaillie Tetrao urogallus: results from a stochastic model. Wildl. Biol. 6: 259-265.

Harris, R. B. (1986) Reliability of trend lines obtained from variable counts. J. Wildl. Manag. 50: $165-171$.

IUCN (2001a). IUCN Red List categories. Version 3.1. Prepared by the UICN/SSC. Gland, Switzerland and Cambridge, U.K.: IUCN.

IUCN (2001b) Guidelines for assessing taxa with widely distributed or multiple populations against Criterion A. Prepared by the UICN/SSC/SPS. Gland, Switzerland and Cambridge, U.K.: IUCN.

London Times (1999) The Times atlas of the world. Tenth comprehensive edition. London.

Ménoni, E. and Magnani, Y. (1998) Human disturbance of grouse in France. Grouse News 15:4-8.

Moss, R., Picozzi, N. and Catt, D. C. (1991) Capercaillie ecology. Forestry Commission Report on Forest Research.

Moss, R., Oswald, J. and Baines, D. (2001) Climate change and breeding success: decline of the capercaillie in Scotland. J. Anim. Ecol. 70: 47-61.

Obeso, J. R. and Bañuelos, M. J. (2003) El Urogallo (Tetrao urogallus cantabricus) en la Cordillera Cantábrica. Madrid: Ministerio de Medio Ambiente.

Pollo, C. J. (2001) El Urogallo cantábrico: situación actual y actuaciones de futuro. Medio Ambiente en Castilla y León 16: 14-26.

Pollo, C. J., Robles, L., Seijas, J., García-Miranda, A. and Otero, R. (2003a) Cantabrian Capercaillie Tetrao urogallus cantabricus population size and range trend. Will the capercaillie survive in the Cantabrian Mountains? Grouse News 26: 3-5.

Pollo, C. J., Robles, L., García-Miranda, A., Otero, R. and Obeso, J. R. (2003b) Variaciones en la densidad y asociaciones espaciales entre ungulados silvestres y Urogallo cantábrico. Ecología 17: 199-206.

Pollo, C. J., García-Miranda, A. and Robles, L. (in press.) Uso del hábitat por el Urogallo (Tetrao urogallus cantabricus) en la vertiente meridional de la Cordillera Cantábrica. El efecto de la fragmentación forestal. Naturalia Cantabriacae 3.

Potapov, R. L. and Flint, V. E. (1989) Handbuch der Vögel der Sowjetunion. Volume 4. Galliformes, Gruiformes. Wittenberg Lutherstadt, Germany: Ziemsen. 
Rodríguez, A. E. and Obeso, J. R. (2000) Diet of the Cantabrian Capercaillie: geographic variation and energetic content. Ardeola 47(I): 77-83.

Rolstad, J. (1989) Habitat and range use of capercaillie Tetrao urogallus L. in southcentral Scandinavian boreal forests with special reference to the influence of modern forestry. Unpublished PhD thesis, Agricultural University of Norway.

Rolstad, J. (1991) Consequences of forest fragmentation for the dynamics of bird populations: conceptual issues and the evidence. Biol. J. Linn. Soc. 42: 149-163.

Rolstad, J. and Wegge, P. (1989) Capercaillie Tetrao urogallus populations and modern forestry: a case for landscape ecological studies. Finnish Game Res. 46: 43-52.

Sachot, S. (2002) Viability and management of an endangered capercaillie (Tetrao urogallus) metapopulation. PhD thesis, University of Lausanne.

Segelbacher, G., Hoglund, J. and Storch, I. (2003) From connectivity to isolation: genetic consequences of population fragmentation in capercaillie across Europe. Mol. Ecol. 12: 1773-1780.

Sokal, R. R. and Rohlf, F. J. (1995) Biometry. Third edition. New York: W. H..

Storch, I. (1995) Habitat requirements of Capercaillie. Proc. Int. Symp. Grouse 6: 151-154.

Storch, I. (1997) The importance of scale in habitat conservation for an endangered species: the Capercaillie in Central Europe. Pp: $310-330$ in J. A. Bissonette, ed. Wildife and landscape ecology: effects of pattern and scale. Springer Verlag, New York.

Storch, I., compiler. (2000) Grouse status survey and conservation action plan 2000-2004. Gland, Switzerland, Cambridge, U.K. and Reading, U.K.: WPA/BirdLife/SSC Grouse Specialist Group, IUCN, UK and the World Pheasant Association.

Storch, I. (2001) Capercaillie. BWP update. The Journal of Birds of the Western Palearctic. Oxford: Oxford University Press.

Suchant, R. (2001) Die Entwicklung eines mehrdimensionalen Habitatmodells für Auerhuhnareale (Tetrao urogallus L.) als Grundlage für die Integration von Diversität in die Waldbauparxis. Dissertation, University of Freiburg i.Br., Germany.

Suchant, R. and Schäfer, A. (2002) Monitoring and management of visitor flows in recreational and protected areas. Pp. 95-101 in A. Arnberger, C. Brandenburg \& A. Muhar, eds. Integrating tourism and grouse habitat protection in the Black Forest. Conference proceedings.

Suter, W., Graf, R. F. and Ruedi, H. (2002) Capercaillie (Tetrao urogallus) and avian biodiversity: testing the umbrella-species concept. Conserv. Biol. 16: 778-788.

Valkeajärvi, P. and Ijäs, L. (1993) On the display requirements of Capercaillie in central Finland. Suomen Riista 33: 5-18.

Zar, J. (1984) Biostatistical analysis. Second edition. Rahway, NJ: Prentice-Hall.

Zeitler, A. and Glänzer, V. (1998) Skiing and grouse in the Bavarian Alps. Grouse News 15: 8-12.

CÉSAR J. POLLO, LUIS ROBLES, JUAN SEIJAS, ÁNGEL GARCÍA-MIRANDA and RAFAEL OTERO

Sección de Espacios Naturales y Especies Protegidas, Servicio Territorial de Medio Ambiente, Junta de Castilla y León, Avda. de Peregrinos, s/n, 24071, León, Spain. Email: polmatce@jcyl.es

Received 27 July 2004; revision accepted 21 April 2005 